\title{
Shifting Patterns of Pre-Service Teachers' Conceptions on Material of Colligative Properties of Solutions
}

\author{
Harun Nasrudin* , Utiya Azizah \\ Chemistry Department \\ Universitas Negeri Surabaya \\ Surabaya, Indonesia \\ harunnasrudin@unesa.ac.id
}

\begin{abstract}
This study aims to describe the shifting patterns of pre-service teachers' conceptions on the material of colligative properties of solutions. The occurred misconceptions were then overcome using metacognitive learning strategy. The pre-service teachers' conception status was determined by the results of diagnostic tests using multiple choice format supplemented with Certainty of Response Index (CRI). The subjects were pre-service teachers studying chemical education program at Universitas Negeri Surabaya, Indonesia. The study used one group pretest-posttest design. The obtained data were analyzed using descriptive quantitative approach. Results showed that there were five shifting patterns of the pre-service teachers' conceptions: (1) from misconception into knowledge of correct concept $10.53 \%$, (2) from potentially knowledge of correct concept into stagnant or better mastery $70.18 \%$, (3) from potentially misconception into lack of knowledge $8.77 \%$, (4) from potentially knowledge of correct concept into misconception $3.51 \%$ and (5) from misconception remained in the same category $7.02 \%$.
\end{abstract}

Keywords - shifting patterns of conceptions, misconception, CRI, colligative properties of solution

\section{INTRODUCTION}

Chemistry is a form of logical science complemented by ideas with several interesting applications for daily-life phenomena. Commonly, whole objects existing in this world are a mixture of complex chemical substances [1]. Chemistry consists of concepts that are abstract and multifaceted so that it requires a gradual and deep understanding to master. Low learning outcomes indicate low learners' understanding of chemistry concept. In chemistry, there are often occurred interconnected concepts that require profound conceptions to attain correct and easy understanding.

Colligative properties of solutions becomes one of the topics in a basic chemistry course for all pre-service teachers majoring in Chemistry, Biology, Physics, and Mathematics at Mathematics and Science Faculty, Universitas Negeri Surabaya, Indonesia. Within the course implementation, preservice teachers' misconception on the material of colligative properties of solutions were often found. The misconceptions included understanding the concept of vapor pressure related to the influence of solutes, submicroscopic images of the evaporation process of both electrolyte and non-electrolyte substances in accordance to the difference of boiling points, the concept of osmotic pressure, and the relationship between variables namely boiling point elevation and freezing point depression, elegance, molar mass, and Van't Hoff factors.

The results of previous studies found that learning difficulties and misconceptions might occur in the concept of colligative properties of solutions [2]. Similarly, other research results pointed out that there was a misconception experienced by students on the material of colligative properties of solutions, especially on the concept of boiling point elevation and freezing point elevation [3]

The concept laid on an individual's cognitive structure is mostly resulted from experiences. So that, the concept or knowledge perceived by pre-service teachers is the outcome of the experienced learning process that further becomes the foundation of pre-service teachers' thinking process in troubleshooting various problems. Based on constructivist theory, pre-service teachers are often referred to active individuals. When the learning process conducted, they try to connect their schemata with the new concept being learned. Understanding of chemistry is constructed by some underlying prerequisite concepts [4]. Mistakes in connecting schemata with the new obtained concepts might lead to occurring misconceptions. Since chemistry concept is hierarchical, misconceptions occurred on the basic concepts of chemistry can drive to further misconceptions for the upcoming concepts [5].

Misconception refers to any irrelevant concepts to scientific understanding received by all experts in a particular field. Misconception is a wrong idea with resistant and persistent characteristics about a certain concept portrayed by those who have different understanding from the agreed and considered-right concept [6; 7]. Misconception becomes a huge obstacle in more meaningful learning [8].

That is, a study examining pre-service teachers' misconceptions on the colligative properties of solutions is necessary to be done to redirect pre-service teachers' conceptions into the right paths. If they cannot master the whole concepts well, their misconception will be transmitted to their students, which potentially causes implicative problems that obstruct the learning process. Therefore, preservice teachers' misconceptions must be immediately corrected, or better prevented, to lead them not to possess a wrong conception of the whole chemical materials. 


\section{METHODS}

There were 22 pre-service teachers majoring on Chemical Education at Universitas Negeri Surabaya chosen as the participants of this study. They studied colligative properties of solutions using metacognitive learning strategy. Metacognitive learning strategy was chosen to be used in the present study due to the successful implementation in the previous study focusing on enhancing pre-service teachers' learning attainments on hydrolysis and buffer solution [9].

This study used one group pretest-posttest design [10] The identification of the achievement of pre-service teachers' understanding was carried out by using a diagnostic test with multiple choice format supplemented with CRI. There were 11 items included in the test covering four colligative properties of solutions namely vapor pressure reduction, boiling point elevation, freezing point depression, and osmotic pressure.

The use of a diagnostic test with multiple choice items that included responses to the learned concepts were appropriate to let pre-service teachers choose the provided reasons that matched with the selected answers [11]. CRI referred to a confidence level scale in answering each question. Discrepant levels of confidence perceived by preservice teachers in answering the questions were referred to Hasan's classification [12] (see Table 1).

TABLE I.

CONFIDENCE LEVEL IN ANSWERING QUESTIONS

\begin{tabular}{|c|l|}
\hline Scale & \multicolumn{1}{|c|}{ Level } \\
\hline 0 & Totally guessed answer \\
\hline 1 & Almost a guess \\
\hline 2 & Not Sure \\
\hline 3 & Sure \\
\hline 4 & Almost certain \\
\hline 5 & Certain \\
\hline
\end{tabular}

Based on the achievement of pre-service teachers' understanding concept, there were three groups of conceptions namely knowledge of correct concept (KCC), do Lack of knowledge (LK), and misconceptions (M), which were based on Certainty of Response Index (CRI). Table 2 shows the criteria of determining those who should be included in either KCC, LK, or M categories.

TABLE II. CRITERIA TO DETERMINE PRE-SERVICE TEACHERS' CONCEPTION CATEGORIES

\begin{tabular}{|c|l|l|}
\hline & \multicolumn{1}{|c|}{ Low CRI (<2.5) } & \multicolumn{1}{c|}{ High CRI (> 2.5) } \\
\hline $\begin{array}{c}\text { Correct } \\
\text { answer }\end{array}$ & $\begin{array}{l}\text { Correct answer and low } \\
\text { average CRI (CL) } \\
\text { Lack of knowledge } \\
\text { (lucky guess) }\end{array}$ & $\begin{array}{l}\text { Correct answer and } \\
\text { high average CRI (CH) } \\
\text { Knowledge of correct } \\
\text { concepts }\end{array}$ \\
\hline $\begin{array}{c}\text { Wrong } \\
\text { answer }\end{array}$ & $\begin{array}{l}\text { Wrong answer and low } \\
\text { average CRI (WL) } \\
\text { Lack of knowledge }\end{array}$ & $\begin{array}{l}\text { Wrong answer and high } \\
\text { average CRI (WH) } \\
\text { Misconceptions }\end{array}$ \\
\hline
\end{tabular}

\section{RESULTS AND DISCUSSIONS}

Through diagnostic tests using multiple choice format supplemented with Certainty of Response Index (CRI), obtained the result as follows.

\section{A. Pre-service Teachers' Initial Conception Profile}

Fig. 1 depicts the pre-service teachers' initial conception profile on the material of colligative properties of solutions before a conducted learning process using metacognitive strategy.

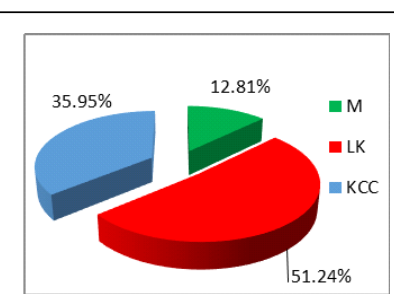

(a)

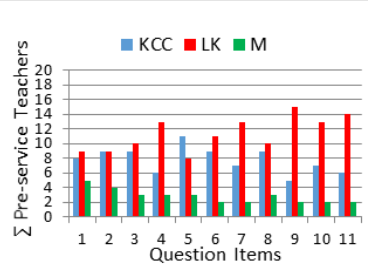

(b)
Fig. 1. Pre-service teachers' initial conception profile based on total scores (a) and specific questions numbers (b)

Fig. 1a depicts the fact that pre-service teachers perceived LK and M categories as their initial conception status for almost all materials in colligative properties of solutions. In short, the total numbers of pre-service teachers with LK and $\mathrm{M}$ categories $(64.05 \%)$ were higher than those in KCC category (35.95\%). Meanwhile, Fig. $1 \mathrm{~b}$ describes the numbers of pre-service teachers' conceptions for each item regarding the materials of colligative properties of solutions conducted in pre-learning activities. The big numbers of preservice teachers who did not know the concept and experienced misconceptions were caused by difficult understanding toward scientific phenomena [13]. Such tough understanding raised by those in KCC category was due to inconstant conceptions proven by fluctuating or not consistent KCC's bars shown in Figure $1 b$.

In the material of colligative properties of solutions, the most significant concept for happening misconception was indicated by items number 1 and 2. These two items presented the concepts of vapor pressure related to the effect of solutes presence and submicroscopic images on the evaporation process of electrolyte and non-electrolyte substances related to their boiling points. On the contrary, there were five items that made pre-service teachers perceive low misconception namely items 6, 7, 9, 10, and 11 . Respectively, the items consisted the concepts of the relationships between boiling point elevation and molality, boiling point elevation and molar mass, freezing point depression and Van't Hoff factors, and solution's concentration and the osmotic pressure. The pre-service teachers' initial conception profile was necessary to reveal and to consider for lecturers. The initial conception is a depiction of the originality of one's understanding that can be used as further considerations in devising and implementing learning design [14].

\section{B. Pre-service Teachers' Conception Profile after Learning Process}

Fig. 2 shows pre-service teachers' post conception profile treated by using metacognitive learning strategy with three skills involved namely planning, monitoring, and evaluation. 


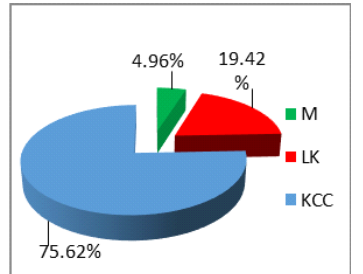

(a)

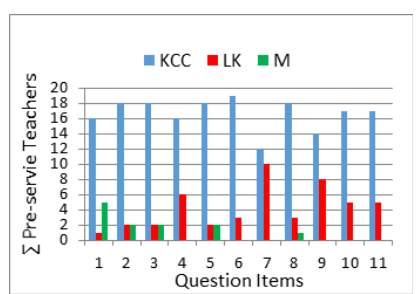

(b)
Fig. 2. Pre-service teachers' conception profile after the hole learning process (a) and specifically portrayed by each question item (b)

Fig. 2a shows that there were still several remaining items that conveyed the possible presence of misconceptions, except for question item 4, 6, 7, 9, 10 and 11 . The percentage of those in KCC and M categories (24.38\%) was lower than those in KCC category (75.62\%). In short, the results were the opposite of the pre-service teachers' initial conception profile. Meaning that, the majority of the pre-service teachers dominated the KCC category after the conducted learning process using metacognitive strategy. In addition, Fig. 2b shows constant KCC's bars for each question item, which meant that the pre-service teachers already mastered each concept in the material of colligative properties of solutions.

Before the conducted learning process using metacognitive strategy, the highest misconception occurred in the concept of vapor pressure related to the influence of solutes and the concept of submicroscopic images of the evaporation process of electrolyte and non-electrolyte substances related to different boiling points (questions item 1 and 2). Based on Fig. 2b, the misconception occurred in item 1 remained unchanged while the misconception in item 2 was decreased from four to two pre-service teachers.

Some concepts that previously had low misconception status changed into no-misconception status revealed by items $6,7,9,10$, and 11 . The five items respectively represented the concepts of the relationship between the raise of boiling point and molality, boiling point elevation and molar mass, freezing point depression and Van't Hoff factors, and the solution concentration and the solutions' osmotic pressure. As an implication, learning process using metacognitive strategy consisting planning, monitoring, and evaluation skills was able to reduce pre-service teachers' misconception. Misconceptions are resistant or difficult to change and tend to be persistent [15]. Although students had been corrected and introduced with the right concept, there was still a possibility to return to its own original conception which was wrong (misconception) [6].

\section{Shifting Patterns of Pre-service Teachers' Conceptions}

There were five shifting patterns of pre-service teachers' conceptions: (1) the pre-service teachers in $\mathrm{M}$ category shifted into KCC category, (2) those in KCC category changed into better conceptions, (3) those in M category shifted into LK category, (4) those in KCC category became $M$, and (5) those in $M$ category still remained in the same category. Fig. 3 provides the portrayal of the shifting patterns.

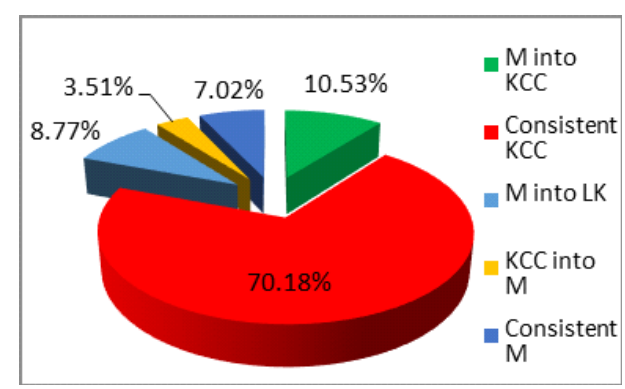

Fig. 3. The map of the shifting patterns of pre-service teachers' conceptions on the material of colligative properties of solutions

After using metacognitive learning strategy with planning, monitoring, and evaluation skills, there was a shifting conception on the material of colligative properties. For instance, $10.53 \%$ of the pre-service teachers shifted from $\mathrm{M}$ into $\mathrm{KCC}$ category, $70.18 \%$ of them remained in $\mathrm{KCC}$ category, $8.77 \%$ of them shifted from M into LK category, $3.51 \%$ of them changed from KCC into M category, and the rest $7.02 \%$ of them remained in $\mathrm{M}$ category.

Above findings portrayed that correcting misconceptions was difficult even if the efforts undertaken had been nearly successful in alleviating pre-service teachers' misconception problems [16]. Phenomena were natural because not a few experts in education felt difficult to correct students' misconceptions. Some students who initially perceived misconceptions would experience cognitive problem and confusion regarding particular concepts. As a result, they might face difficult to believe in their new acquired concepts, of which such situation promoted more tremendous problems in learning process.

\section{CONCLUSION}

This study concludes that there are five shifting patterns of pre-service teachers' conceptions covering from misconception into knowledge of correct concept categories $10.53 \%$, from knowledge of correct concept remained in the same category $70.18 \%$, from misconception into lack of knowledge categories $8.77 \%$, from knowledge of correct concept into misconception categories $3.51 \%$, and from misconception remained in the same category $7.02 \%$.

\section{REFERENCES}

[1] R. Chang, General Chemistry: The essential Concepts. 5th ed. Boston: McGraw-Hill Companies, 2008.

[2] P. Tacettin, S. Mustafa, and C. Nurtac, "Prospective chemistry teachers' misconceptions about colligative properties: Boiling point elevation and freezing point depression." Chemistry Education Research and Practic, 2009. vol 10, no 4, pp. 273-280.

[3] N.E. Luoga, P.A. Ndunguru, and S.L Mkoma, High School Students' Misconceptions about Colligative Properties in Chemistry, tanzania Journal of Natural \& Applied Science, 2013, vol 4, no 1, pp. 575581.

[4] C. O'Connor, A Practice-Led Approach to Aligning Learning Theories with Learning and Teaching Strategies in Third Level 
Chemistry Education.Irish Journal of Academic Practice, 2015, vol 4, no 1 , pp. $0-17$.

[5] G. Tsaparlis, D. Kolioulis, \& E. Pappa, Lower Secondary Introductory Chemistry Course: A Novel Approach Based on Science-Education Theories, with Emphasis on the Macroscopic Approach, and the Delayed Meaningful Teaching of the Concepts of Molecule and Atom. Chemistry Education Research and Practice, 2010, vol 11, pp 107-117.

[6] M. Ibrahim, Konsep, Miskonsepsi dan Cara Pembelajarannya. Surabaya: Unesa University Pres, 2012.

[7] P. Suparno, Miskonsepsi dan Perubahan Konsep Pendidikan Fisika. Jakarta: PT. Gramedia Widiasarana Indonesia, 2005.

[8] A. Pabuccu and O. Geban, "Remediating Misconceptions Concerning Chemical Bonding Through Conceptual Change Text." Journal of Education, 2006, vol 30, pp 184-192.

[9] U. Azizah and H. Nasrudin, Empowerment of metacognitive skills through development of instructional materials on the topic of hydrolysis and buffer solutions. Journal of Physics: Conference Series, 2018, https://doi:10.1088/1742-6596/953/1/012199.

[10] J.R. Fraenkel and N.E. Wallen, How to design and evaluate research in education. Fifth Edition. Boston: Mc Graw Hill, 2003.

[11] A,L, Chandrasegaran, F.T. Davit and M. Mauro, The Development of a Two-tier Multiple Choice Diagnostic Instrument of Evaluating
Secondary School Student Ability to Describe and Explain Chemical Reaction Using Multiple Level of Representation. The Royal Society of Chemistry, 2007, pp. 293-307.

[12] S. Hasan, B. Diola, and L.K. Ella, Misconceptions and the Certainty of Response Index (CRI). Journal: Physics Educations, 1999, vol 34, no 5, pp. 294-299.

[13] R.M. Best, M. Roe, Y. Ozuru, D.S. McNamara, "Deep-Level Comprehension of Science Texts The Role of the Reader and the Text." Top Lang Disorders. 2005, vol 25, no 1, pp. 65-83.

[14] H.D. Barke, Al Hazari, and S. Yitbarek, Misconceptions in Chemistry, Addressing Perception in Chemical Education. 2009, Berlin Heidelberg: Spinger-Verlag.

[15] M.R. Abraham, E.B. Grzybowski, J. W. Renner, and E.A. Marek, Understandings and Misunderstandings of Eight Graders of Five Chemistry Concepts Found in Chemistry Textbooks, Journal of Research in Science Teaching, 1992. Vol 29, no 2, pp 105-120.

[16] Chiu, Mei-Hung; Jing-Wen; and Liang, Jia-Chi, An Exploratory Study on Causes of Students' Misconception about Acids and Bases. Paper presented at the International Conference on Svience \& Mathematics Learning. 2005, Taipei, Taiwan, ROC. 